\title{
Ropień zaotrzewnowy jako powikłanie ostrego zapalenia wyrostka robaczkowego położonego zakątniczo, przebijający się do jamy otrzewnowej i manifestujący się objawami przedziurawienia przewodu pokarmowego - opis przypadku
}

\section{Retroperitoneal abscess as a complication of retrocecal acute appendicitis, perforated into the peritoneal cavity and presenting as a perforation of the digestive tract - a case report}

\author{
Piotr Puchalski, Wojciech Jagielski, Andrzej Żyluk ${ }^{凶}$ \\ Pomorski Uniwersytet Medyczny w Szczecinie, Klinika Chirurgii Ogólnej i Chirurgii Ręki, ul. Unii Lubelskiej 1, 71-252 Szczecin \\ $\triangle$ azyluk@hotmail.com
}

\begin{abstract}
We report the case of a retroperitoneal abscess which developed within 2 weeks after an episode of retrocecally localized acute appendicitis. The abscess perforated into the pritoneal cavity, which clinically and radiologically mimicked perforation of the digestive tract and required surgical intervention. Intraoperatively, a correct diagnosis was made and adequate treatment
\end{abstract}

was applied consisting in the evacuation and drainage of the abscess, as well as resection of remnants of the appendix, resulting in the recovery of the patient. Culture of the pus taken from the abscess showed no bacterial growth. The paper discusses some atypical aspects of the clinical course in the presented case. Keywords: retroperitoneal abscess; acute appendicitis; complications; gas in the peritoneal cavity.

\section{ABSTRAKT}

Opisano przypadek ropnia zaotrzewnowego, który wytworzył się w ciągu 2 tyg. od epizodu ostrego zapalenia wyrostka robaczkowego położonego zakątniczo. Ropień przebił się do jamy otrzewnej, dając kliniczne i radiologiczne objawy przedziurawienia przewodu pokarmowego, co było powodem interwencji chirurgicznej. W trakcje operacji rozpoznano właściwie przyczynę choroby, a zastosowane leczenie: ewakuacja ropnia, drenaż jego jamy i wycięcie resztek wyrostka robaczkowego było skuteczne i skutkowało wyzdrowieniem. Badanie bakteriologiczne treści z ropnia nie wykazało wzrostu żadnych bakterii. W pracy omówiono kilka nietypowych elementów przebiegu klinicznego opisywanego przypadku.

Słowa kluczowe: ropień zaotrzewnowy; ostre zapalenie wyrostka robaczkowego; powikłania; gaz w jamie otrzewnowej.

\section{WSTĘP}

Ropnie przestrzeni zaotrzewnowej są stosunkowo rzadkim powikłaniem schorzeń różnych narządów jamy brzusznej. Mogą być powikłaniami perforacji przewodu pokarmowego do przestrzeni zaotrzewnowej: owrzodzenia trawiennego lub uchyłka dwunastnicy, zapalenia zmienionego wyrostka robaczkowego lub uchyłka okrężnicy, raka okrężnicy, ale także jatrogennej perforacji dwunastnicy w czasie sfinkterotomii $[1,2,3]$. Inną przyczyną są zapalenia narządów położonych zaotrzewnowo odmiedniczkowego zapalenia nerek i ostrego zapalenia trzustki. Mogą być powikłaniem (zropieniem) pourazowych krwiaków zaotrzewnowych, często obserwowanych u pacjentów ze złamaniami kręgosłupa lędźwiowego i miednicy. Ropnie zaotrzewnowe mogą powstawać w przebiegu choroby Leśniowskiego-Crohna, ropnego zapalenia lub gruźlicy kręgosłupa lędźwiowego albo jako przerzutowe drogą krwionośną, np. w przebiegu bakteryjnego zapalenia wsierdzia.
Objawy ropni przestrzeni zaotrzewnowej są różne, zwykle jednak dolegliwości są odczuwane w okolicy lędźwiowej, a znacznie rzadziej w jamie brzusznej. W zależności od przyczyny ropień może znajdować się w górnej (pochodzenia trzustkowego i dwunastniczego) lub w dolnej (pochodzenia okrężniczego, wyrostkowego, urazowego) części tułowia. Ze względu na brak barier anatomicznych cechą charakterystyczną tej patologii jest skłonność do szerzenia się w luźnej tkance łącznej, co sprzyja osiąganiu znacznych rozmiarów i nadaje im charakter ropowicy. $Z$ tego też powodu szybko mogą powodować posocznicę, szczególnie u osób w podeszłym wieku, chorych na cukrzycę i z osłabioną odpornością.

W pracy opisano przypadek ropnia zaotrzewnowego, który wytworzył się w ciągu 2 tyg. od epizodu ostrego zapalenia wyrostka robaczkowego położonego zakątniczo. Ropień przebił się do jamy otrzewnej, dając kliniczne i radiologiczne objawy przedziurawienia przewodu pokarmowego, co było powodem szybkiej interwencji chirurgicznej. 
W trakcje operacji rozpoznano właściwie przyczynę choroby, a zastosowane leczenie było skuteczne i skutkowało wyzdrowieniem.

\section{SPOSTRZEŻENIE WŁASNE}

Pacjentka, 68-letnia kobieta, została przywieziona z domu ambulansem Pogotowia Ratunkowego do Szpitalnego Oddziału Ratunkowego z powodu silnego bólu całego brzucha, wymiotów i znacznego osłabienia. Z wywiadu uzyskano następujące informacje:

- ból prawej strony brzucha trwał od ok. 2 tyg., a 2 dni przed wezwaniem pogotowia znacznie się nasilił i obejmował całą jamę brzuszną,

- ból zmniejszał się przy leżeniu na prawym boku i podczas chodzenia, a nasilał przy oddawaniu stolca,

- chora nie gorączkowała,

- od 20 lat leczyła się z powodu miażdżycy tętnic obu kończyn dolnych (3-krotnie PTA + stenty).

Badaniem przedmiotowym stwierdzono:

- pacjentka leżąca, w stanie ogólnym średnim, otyła, cierpiąca przy każdej zmianie pozycji ciała,

- brzuch napięty, lekko wzdęty, bolesny przy badaniu na całej powierzchni z wyraźnymi objawami otrzewnowymi,

- osłuchiwaniem brak słyszalnej perystaltyki.

Badania biochemiczne wykazały podwyższone parametry stanu zapalnego: liczba leukocytów $11 \mathrm{G} / \mathrm{L}$, stężenie białka C-reaktywnego (CRP) 320 mg/L, stężenie D-dimerów $4,17 \mu \mathrm{g} / \mathrm{mL}$, stężenie fibrynogenu $614 \mathrm{mg} / \mathrm{dL}$.

Na podstawie przeglądowego RTG jamy brzusznej wykazano obecność gazu pod obiema kopułami przepony (ryc. 1).

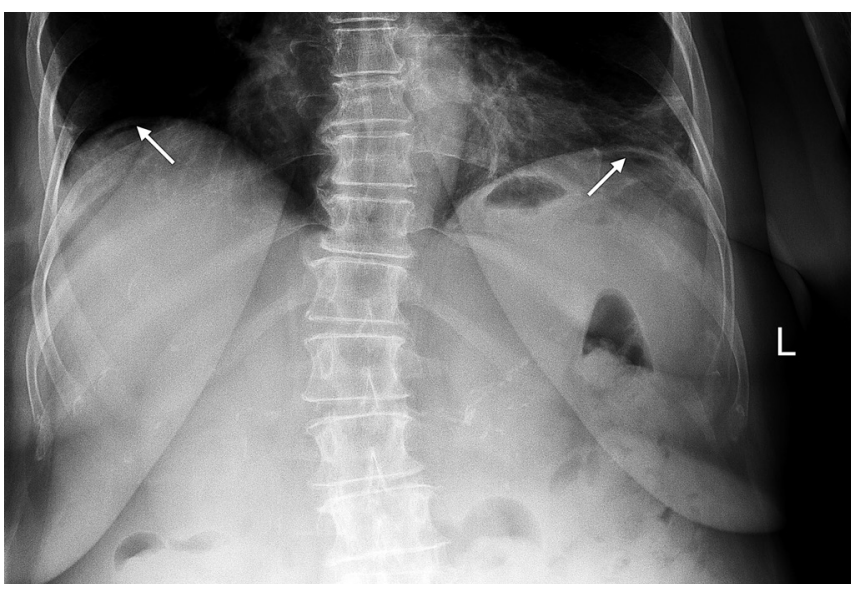

RYCINA 1. Zdjęcie przeglądowe jamy brzusznej wykazujące gaz pod obiema kopułami przepony (zaznaczony strzałkami)

Obraz kliniczny i wyniki badań dodatkowych wskazywały jednoznacznie na przedziurawienie przewodu pokarmowego jako przyczynę choroby. Wobec takiej sytuacji nie wykonywano innych badań i przyjęto chorą na oddział chirurgiczny oraz zaplanowano pilną laparotomię. Przed operacją podano profilaktyczne dawki antybiotyku - 2 g cefazoliny i $1 \mathrm{~g}$ metronidazolu (dawki 2-krotnie większe od standardowo stosowanych ze względu na znaczną nadwagę).

\section{SPOSTRZEŻENIA ŚRÓDOPERACYJNE}

Jamę otrzewnową otwarto z cięcia pośrodkowego w nadbrzuszu przechodzącego do połowy podbrzusza. Po otwarciu otrzewnej stwierdzono między pętlami jelita cienkiego umiarkowaną objętość ropy i mętnego płynu, który pobrano do badania bakteriologicznego i ewakuowano. Płyn nie był podbarwiony żółcią i nie miał charakteru (wyglądu ani zapachu) kałowego. Badanie okolicy żołądka i dwunastnicy nie wykazało obecności perforacji, podobnie oglądanie jelita grubego.

W czasie inspekcji podbrzusza w okolicy nadpęcherzowej zaobserwowano, że z przestrzeni zaotrzewnowej przez otwór o średnicy $1 \mathrm{~cm}$ wydobywa się pod ciśnieniem treść ropna. Poszerzono otwór i zrewidowano wnętrze ropnia, nie stwierdzając jego penetracji do innych narządów. Po prawej stronie od otworu znajdował się konglomerat pętli jelita cienkiego przyrośnięty do tylnej ściany jamy brzusznej, który częściowo rozpreparowano, odsłaniając nacieczoną kątnicę. Jama ropnia zaotrzewnowego dochodziła do kątnicy, a podczas ponownej jej rewizji stwierdzono resztki zmienionego zgorzelinowo, położonego zakątniczo wyrostka robaczkowego. Końcowy fragment wyrostka wchodził do jamy ropnia, co wskazywało, że to jego zapalenie było przyczyną powstania ropnia. Bliższą część wyrostka wycięto i wysłano do badania histopatologicznego. Jamę otrzewnową i jamę po ropniu wypłukano, założono 2 dreny i zamknięto brzuch warstwowo, pozostawiając niezwiązane (odroczone) szwy skórne.

\section{PRZEBIEG POOPERACYJNY}

Po operacji kontynuowano antybiotykoterapię (cefazolin $3 \times 1 \mathrm{~g}$ i metronidazol $3 \times 0,5 \mathrm{~g}$ ), profilaktykę przeciwzakrzepową i podawano dożylnie płyny. Z drenu ewakuowało się ok. 200-300 mL mętnej treści na dobę. W 2. dobie pooperacyjnej pacjentkę uruchomiono i rozpoczęto żywienie doustne. Wynik badania bakteriologicznego materiału pobranego w trakcie operacji był ujemny: nie stwierdzono wzrostu bakterii tlenowych ani beztlenowych. Pomimo tego kontynuowano dożylną antybiotykoterapię przez kolejne 5 dni. Dreny usunięto w 4. dobie. Przebieg pooperacyjny był powikłany zakażeniem rany operacyjnej, mimo jej pozostawienia do gojenia częściowo „na otwarto”. Stan ogólny pacjentki stopniowo się poprawiał, chociaż utrzymywało się znacznie podwyższone (ponad $200 \mathrm{mg} / \mathrm{L}$ ) stężenie CRP. W 7. dobie po operacji pacjentkę wypisano do domu w stanie dość dobrym, z częściowo zagojoną raną. Chociaż nie było potwierdzenia zakażenia bakteryjnego, ambulatoryjnie kontynuowano antybiotykoterapię doustną amoksycyliną. Po 3 tyg. od wypisania uzyskano zamknięcie rany operacyjnej. Na podstawie badania histopatologicznego fragmentu wyrostka robaczkowego wykazano jego zgorzelinowe zapalenie, bez innych zmian patologicznych. 


\section{OMÓWIENIE}

Opisany przypadek ropnia przestrzeni zaotrzewnowej jest ciekawy z kilku powodów:

- przyczyna powstania ropnia - ostre zapalenie wyrostka robaczkowego położonego zakątniczo,

- nietypowy przebieg kliniczny ostrego zapalenia wyrostka robaczkowego (OZWR),

- przebicie się ropnia do jamy otrzewnowej i powstanie rozlanego, ropnego zapalenia otrzewnej,

- obecność gazu pod kopułami przepony na RTG przeglądowym jamy brzusznej, co - zgodnie z zasadami - zinterpretowano jako przedziurawienie przewodu pokarmowego,

- brak potwierdzenia zakażenia bakteryjnego w badaniu bakteriologicznym.

Wydaje się, że scenariusz kliniczny prowadzący do powstania ropnia zaotrzewnowego był następujący:

- choroba rozpoczęła się ostrym zapaleniem wyrostka robaczkowego położonego zakątniczo, 2 tyg. przed przyjęciem do szpitala, co manifestowało się umiarkowanie nasilonym, trudnym do zlokalizowania bólem prawej strony brzucha,

- zapalnie zmieniony wyrostek uległ zgorzeli i perforował do przestrzeni zaotrzewnowej, co rozpoczęło proces powstawania ropnia w tej okolicy; w trakcie powstawania ropnia wytworzył się gaz, który wypełniał jego jamę,

- po ok. 2 tyg. powierzchownie zlokalizowany ropień przebił się do jamy otrzewnowej, co wywołało kliniczne objawy rozlanego zapalenia otrzewnej,

- wydobywający się z jamy ropnia gaz wypełnił jamę otrzewnową i był widoczny pod obiema kopułami przepony na zdjęciu przeglądowym jamy brzusznej.

Przebieg omawianego przypadku był w kilku elementach nietypowy, a towarzyszące mu zjawiska trudne do wytłumaczenia. Przebieg OZWR w niczym nie przypominał objawów tej choroby, nawet przy lokalizacji zakątniczej wyrostka. Nietypowy był także brak podwyższenia ciepłoty ciała przez cały okres choroby, nawet po przebiciu się ropnia do jamy otrzewnowej (u osoby dotychczas zdrowej i bez zaburzeń odporności). Trudny do wytłumaczenia był także ujemny wynik posiewu treści z ropnia, a potem z rany operacyjnej wykazującej typowe objawy zakażenia.

Leczenie operacyjne wdrożone w trybie pilnym było prawidłowe: potwierdzono rozlane, ropne zapalenie otrzewnej; wykonano kontrolę przewodu pokarmowego, która nie wykazała przedziurawienia; wykryto miejsce wydobywania się treści ropnej z przestrzeni zaotrzewnowej i przyczynę powstania ropnia; wykonano ewakuację ropnia i wycięto resztki zmienionego wyrostka robaczkowego. Zastosowane leczenie było skuteczne i pacjentka ostatecznie wyzdrowiała.

Ropnie przestrzeni zaotrzewnowej jako powikłanie położonego zakątniczo OZWR są rzadkie.
Ofrim i Legrand przedstawiają przypadek 53-letniego mężczyzny, u którego ropień przestrzeni zaotrzewnowej rozwinął się w ciągu 4 dni po laparoskopowym wycięciu zgorzelinowego, perforowanego, położonego zakątniczo wyrostka robaczkowego. Stan pacjenta nagle pogorszył się w 4. dobie po operacji, z objawami posocznicy, wysokimi parametrami stanu zapalnego i prokalcytoniny. Na podstawie tomografii komputerowej (TK) jamy brzusznej wykazano rozległy ropień przestrzeni zaotrzewnowej po stronie prawej sięgający od dolnego bieguna prawej nerki do prawej kości krzyżowej. Ewakuację i drenaż ropnia przeprowadzono od strony lędźwiowej, przez prawostronną lumbotomię. Badanie bakteriologiczne wykazało zakażenie bakteriami beztlenowymi Acinetobacter i Flavobacterium [4].

Hsieh i wsp. dokonali metaanalizy piśmiennictwa, w którym zaprezentowano przypadki ostrego zapalenia wyrostka robaczkowego powikłanego wytworzeniem się ropni zaotrzewnowych. W piśmiennictwie z lat 1955-2005 znaleziono opisy 24 przypadków takiej patologii, z których 21 (87\%) dotyczyło osób dorosłych, a 7 (29\%) w wieku podeszłym. W żadnym przypadku choroba nie przebiegała typowo, a tylko 9 (37\%) pacjentów miało dolegliwości brzuszne. Odstęp czasu między pierwszymi objawami a rozpoznaniem wynosił średnio 16 dni, natomiast właściwa diagnoza opierała się w większości przypadków na wyniku badania TK brzucha, które ujawniło obecność ropni zaotrzewnowych oraz u części chorych ropowicę zajmującą okolicę okołonerkową, mięśnie pośladkowe, tylną część uda i boczną ścianę jamy brzusznej. Leczenie polegało na appendektomii, ewakuacji i drenażu ropnia/ropowicy zaotrzewnowej, najczęściej przez okolicę lędźwiową. Z powodu posocznicy zmarły 4 osoby (17\%), natomiast pozostali chorzy wyzdrowieli, a średni czas pobytu w szpitalu wynosił $27 \mathrm{dni}$ [5].

Ani w piśmiennictwie, ani w cytowanej metaanalizie autorzy nie przedstawili żadnego przypadku, który przebiegałby z objawami wskazującymi na przedziurawienie przewodu pokarmowego, tak jak w niniejszej prezentacji.

\section{PIŚMIENNICTWO}

1. Fanning DM, Barry M, O’Brien GC, Leahy AL. Perforation of a retrocaecal appendix presenting clinically as a right lumbar abscess. Surgeon 2007;5:368-70

2. Cacurri A, Cannata G, Trastulli S, Desiderio J, Mangia A, Adamenko O, et al. A rare case of perforated descending colon cancer complicated with a fistula and abscess of left iliopsoas and ipsilateral obturator muscle. Case Rep Surg 2014;2014. doi: 10.1155/2014/128506.

3. Sadatomo A, Koinuma K, Zuiki T, Lefor AT, Yasuda Y. Retroperitoneal abscess associated with a perforated duodenal ulcer. Clin J Gastroenterol 2013;6:373-7.

4. Ofrim OI, Legrand MJ. Retroperitoneal abscess resulting from perforated retrocecal appendicitis:a case report. Acta Chir Belg 2013;113:149-51.

5. Hsieh CH, Wang YC, Yang HR, Chung PK, Jeng LB, Chen RJ. Retroperitoneal abscess resulting from perforated acute appendicitis: analysis of its management and outcome. Surg Today 2007;37:762-7. 